\title{
AN EVALUATION OF THE LUNG FUNCTION OF EIGHT TO TWELVE YEAR OLD, CHILDREN LIVING IN TABLE VIEW, CAPE TOWN
}

\section{WJ Esterhuyse, B Sc (Physio), Lecturer, University of Stellenbosch \\ S H Inwin-Carruthers, M Sc (Physio), Senior Lecturer, University of Stellenbosch}

\section{ABSTRACT}

Two groups of twenty children between the ages of 8 and 12 years, who lived in areas near the petrochemical complex in Table View, were studied to ascertain the prevalence of respiratory disease. A random sample of 15 children from each group was subjected to lung function testing using the ELF. Results showed a higher incidence of respiratory disease in the group living closer to the petrochemical complex, but the sample was too small to show any statistical significance. There was no difference in lung function test results between the two groups, but both groups demonstrated lower values than the predicted norms for their age, weight and height.

\section{OPSOMNING}

Twee groepe, elk bestaande uit twintig kinders tussen die ouderdomme van 8 en 12 jaar wat woonagtig is in die omgewing van die petrochemiese aanleg in Table View, is ondersoek om die voorkoms van longsiektes te bevestig. 'n Ewekansige steekproef van 15 kinders uit elke groep is onderwerp aan longfunksietoetse met the ELF. Die groep wat nader aan die petrochemiese aanleg gewoon het, het 'n hoër voorkoms van longsiektes getoon, maar die steekproef was te klein om statistiese beduidenheid te toon. Daar is geen verskil in longfunksies tussen die twee groepe bewys nie, maar beide groepe het wel laer waardes as die verwagte norme in verhouding tot die onderskeie ouderdom, gewig en lengte bereik.

\section{INTRODUCTION}

During the last decade there has been an increasing awareness of environmental pollution and, in particular, of the effects of pollution on man's health and his continued existence.

In the Cape Peninsula this problem is as pressing as elsewhere. If one drives in the direction of Table View and Bloubergstrand there is always a visible cloud of gaseous smoke which varies in degree and shifts in position according to the wind direction. These gasses originate in the petrochemical industries in this area. Many children in the Table View, Edgemead and Bothasig area undergo daily exposure to the sulphur dioxide ( $\left.\mathrm{SO}_{2}\right)$, ozone $\left(\mathrm{O}_{3}\right)$ and nitrate $\left(\mathrm{NO}_{2}\right)$ gases produced. 1

Physiotherapists and medical doctors practising in these areas confirm that local inhabitants 100 are concerned about the potential threat to their health caused by these pollutants. ${ }^{1}$ At the request of local authorities and the Department of Health, the CSIR conducted an epidemiological study during 1983, in which they investigated the effects of air-pollution on the mortality and morbidity of local inhabitants, with specific reference to respiratory problems. No statistically significant evidence of increased mortality was found in the experimental area. Morbidity was assessed by means of notification of respiratory diseases, completion of questionnaires and self-evaluation of their symptoms by previously identified bronchitis sufferers. An increased incidence of respiratory problems was reported by people living in the experimental area.

In 1988 the Department of Physiotherapy, University of Stellenbosch, conducted a follow-up study aimed at obtaining more objec-

- This article is based upon a group study performed by the following final year students at the University of Stellenbosch: $C$ Ferreira, $L$ Fourie, $N$ Jooste, $D$ Olwage, $E$ Retief, $E$ Sassenberg, $C$ van der Westhuizen, $K$ van Niekerk, $R$ Vos B Sc (Physio) University of Stellenbosch, 1988.

Submitted February 1991, corrections received November 1991. 
tive evidence of the effects of air-pollution on lung functions. This study was conducted on children, as they are considered to be more susceptible to the damaging effects of pollutant gases whilst their lungs are still developing prior to the onset of puberty. ${ }^{2}$ There is a growing belief that respiratory disease in children predisposes to the development of respiratory morbidity and earty mortality in the adult. Repeated lung infections in the child can lead to chronic ainway disease. $^{3}$

Overseas studies on the effects of environmental factors on the respiratory function of children have demonstrated an increased incidence of respiratory symptoms and decreased. pulmonary function in environments where there was a high percentage of sulphur dioxide in the air. Improvement in the quality of the atmosphere resulted in reduction of symptoms and increased lung function. ${ }^{4}$

Pure sulphur dioxide is regarded as a mild respiratory irritant which causes upper airway irritation. By stimulating the sensory nerve endings in the mucous membrane, inhalation of $\mathrm{SO}_{2}$ results in a burning sensation in the nose which inhibits respiration, accompanied by coughing due to laryngeal irritation. Stimulation of the trigeminal nerve endings also causes burning of the eyes with increased tear formation. $\mathrm{SO}_{2}$ can also act as a bronchoconstrictor, causing resistance to airflow accompanied by pain due to irritation of the bronchial mucosa. 5

When $\mathrm{SO}_{2}$ occurs with humidity, sulphuric acid is formed. ${ }^{6}$ $\mathrm{H}_{2} \mathrm{SO}_{4}, \mathrm{NO}_{2}$ and $\mathrm{O}_{3}$ are all pulmonary irritants and penetrate to the lower airways, ${ }^{4}$ resulting in increased respiratory rate and decreased tidal flow, presenting as dyspnoca. 5

\section{METHOD}

The sample was drawn from two well-delineated subdivisions of Table View, Sunridge and Bloubergstrand. These two areas are cocupied by families of similar socio-economic status and have the same prevailing winds, namely south-east $\left(140-210^{\circ}\right)$ and north-west $\left(280-350^{\circ}\right)$. Sunridge lies closer to the petrochemical complex and more directly in line with the prevailing south-easter which blows from the direction of the complex. Bloubergstrand lies outside the area of visible pollution and the Bloubergstrand sample was regarded as the control group, although a certain level of air-pollution cannot be excluded.

Criteria for inclusion in the sample were that the child had to be aged between eight and twelve years, have lived in the area continuously for at least five years and not have any cardiac problems. Potential children for inclusion in the sample were identified by house to house visits and interviews with the parents. When a child was identified as satisfying the criteria, the patents were requested to complete a questionnaire (standardised questionnaire ATS DLD $78 \mathrm{C}^{7}$ ) which was collected the same evening. Due to limited time, only 20 households in each area were identified. From the 40 questionnaires completed, thirty (15 from each area) were drawn randomly and these children underwent lung function tests.

Testing was performed at a central venue, by appointment. On arrival each child was weighed and measured (barefoot). Careful explanation of the lung function tests was given to the child, each child being tested at least twice and up to four times if the child experienced difficulty. The child's best results were recorded. The measuring instrument used was the ELF (Electronic Lung Functions) apparatus, which was programmed to recalibrate automatically before each test. The following parameters were measured:

- FVC (forced vital capacity)

- FEV 1 (forced expiratory volume in 1 second)

- $\mathrm{FEV}_{1} \%$

- FEF25 (forced expiratory flow at $25 \%$ of vital capacity)

- FEF50 (forced expiratory flow at $50 \%$ of vital capacity)

- FEF75 (forced expiratory flow at $75 \%$ of vital capacity)

- PEFR (peak expiratory flow speed)

All measurements were taken and computed by the ELF, which gave an immediate print-out of results and diagnosis. Mean and standard deviation were calculated for each parameter. An independent observer (specialist in internal medicine) identified tests which had been incorrectly performed and these were excluded from the results.

Information derived from the questionnaire was subjected to computer analysis using the REFLEX programme and results were tabulated.

\section{RESULTS}

In the results and discussion the Bloubergstrand sample (further from the petrochemical complex) is designated group $A$ and the Sunridge sample (nearer to the petrochemical complex) is designated group $B$.

The ratio of boys to girls was 9:11 in group $A$ and 6:14 in group B. The mean age of the-group $A$ children was 10,2 years (range 8-12) and that of the group B children was 10,8 years (range 9-12).

\section{Questionnaires}

All 40 questionnaires were returned completed. There was a higher reported incidence of respiratory disease in group $\mathrm{B}$, but because the sample is so small no statistical significance can be attached to the differences in incidence of the various specific diseases (Table 1).

Table 1: Incidence of respiratory disease in Group A (Bloubergrant) and Group B (Sunridge) children

\begin{tabular}{|l|c|c|c|c|}
\hline \multirow{2}{*}{ CONDITION } & \multicolumn{2}{c|}{ GROUP A } & \multicolumn{2}{c|}{ GROUP B } \\
\cline { 2 - 5 } & YES & NO & YES & NO \\
\hline SHRONIC BRONCHITIS & - & 20 & - & 20 \\
\hline ACUTE BRONCHITIS & - & - & - & - \\
\hline ASTHMA & 1 & 18 & 3 & 17 \\
\hline DTHER DISEASES IN 1ST 2YF & 2 & 18 & 4 & 16 \\
\hline SINUSITIS & 3 & 17 & 7 & 13 \\
\hline BRONCHIOUITIS & - & - & - & - \\
\hline BRONCHITIS & 4 & 18 & 9 & 11 \\
\hline ASTHMATIC BRONCHITIS & 1 & 18 & 2 & 18 \\
\hline MIDDLE EAR INFECTION & 7 & 13 & 11 & 8 \\
\hline TOTAL INCIOENCE & 18 & - & 36 & - \\
\hline
\end{tabular}

No difference was found between the groups in the occurrence of the following signs: cough accompanying a cold, cough in the absence of a cold, chest secretions in the absence of a cold. Group B showed a higher incidence of chest secretions accompanying a cold.

A higher incidence of allergies and croup was reported in group $A$ but in both groups the numbers were very small. There were slightly more smokers in group B homes (13:18) but no relationship was found between the incidence of asthma and the number of smokers in the home.

\section{Lung function tests}

Table 2: Average values on lung function testing

\begin{tabular}{|c|c|c|}
\hline PARAMETER & GROUP A & GROUP B \\
\hline FEV1 & 83,5833 & 85,3846 \\
\hline FVC & 104,917 & 107,077 \\
\hline FEV1\% & 89,8687 & 89,6823 \\
\hline FEF25 & 101,917 & 187,308 \\
\hline FEF50 & 82,3333 & 77,8482 \\
\hline FEF75 & 84,75 & 82,6823 \\
\hline PEFR & 81,75 & 101,231 \\
\hline
\end{tabular}


In group $A$ the results of two children had to be excluded because they were unable to carry out the tests correctly. One group B child refused to take the tests, whilst a second child's results had to be excluded due to a mechanical fault. Thirteen sets of lung function tests in each group were thus available for analysis. For each child, the results were correlated with his or her age, weight and height and calculated as a percentage of the predicted values according to Schoenburg. 8

Table 2 compares the average values for the two groups. Graphic representation of the average percentage values reveals no significant differences in lung function between the two groups (Figure 1). In both groups, however, the $\mathrm{FEV}_{1}, \mathrm{FEV}_{1} \%$ and FEF50 are lower than the normal average of $100 \%$ predicted by Schoenburg. Only the FVC in both groups and the PEFR in group B reached normal values.

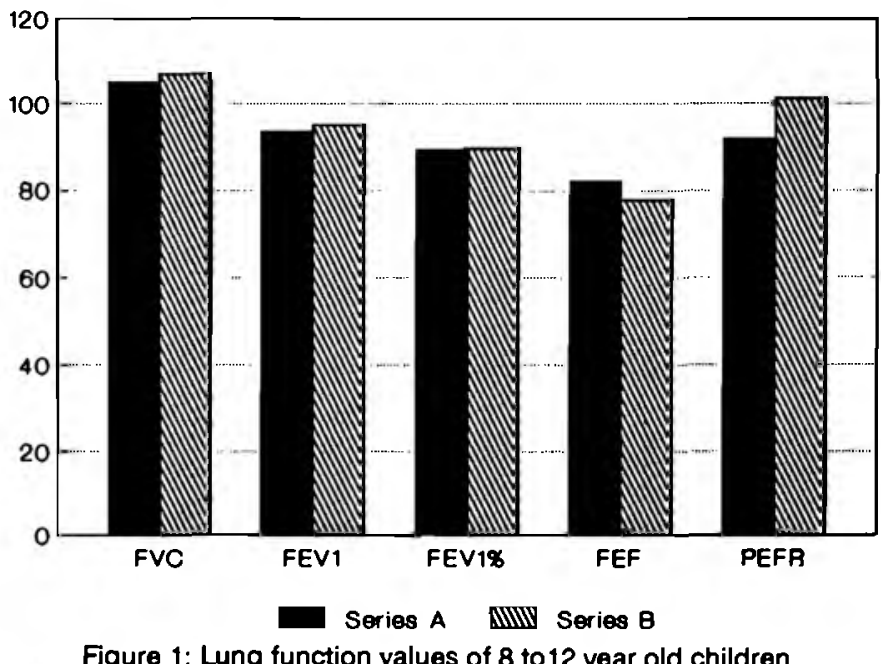

\section{DISCUSSION AND CONCLUSIONS}

The higher reported incidence of respiratory disease in group B children, who lived closer to the petrochemical complex, cannot be regarded as statistically significant due to the small sample size. The higher incidence of smokers in group B parents may also have played a role in the higher incidence of disease in this group. Although no correlation was found between the number of smokers in the house and the number of children who suffered from asthma, a previous study has shown that children's lung functions are adversely affected when their parents, and in particular their mothers, smoke. However, a study carried out in Ohio ${ }^{10}$ also showed a higher reported incidence of acute and chronic respiratory disease in children attending school in an area of raised $\mathrm{SO}_{2}$ and $\mathrm{NO}_{2}$ levels.

No significant difference could be found between the lung functions of the two groups of children, but both groups demonstrated lower values than the predicted norms. ${ }^{8}$ Since the possibility of a degree of air pollution in the area of the control group could not be excluded, a further study of a larger sample of children from suburts bordering on the petrochemical complex is recommended, with a control group from further afield. Although the 1986 CSIR study of the area showed pollution at that time to be within acceptable limits, 1 Mostardi ${ }^{10}$ has suggested that the acceptable limits for atmospheric $\mathrm{SO}_{2}$ and $\mathrm{NO}_{2}$ be redefined.

\section{Acknowledgements}

Thanks are recorded to Professor MA de Kock, former Head of the Department of Internal Medicine, University of Stellenbosch, for the provision of the ELF and for training in its use, and also to Dr $S$ Walsh of the same Department for help in analysing the results.

\section{REFERENCES}

1. Klopper JLM, Harrison JA, Rip MR. Epidemiological studies of health effects associated with air pollution in the Greater Cape Town area, Pretoria, CSIR, 1986.

2. Leeder SR, Corkhill RT, Irwin LM et al. Influence of fa mily factors on the incidence of lower respiratory illness during the first year of life. Br J Prev Soc Med 1976;30:203-212.

3. Sharratt MT, Cherny F. Pulmonary function and health status:a pilot study 19711974. Arch Environ Health 1979;34:114-119.

4. Kagawa JUN, Toshio MD, Toyama MD. Pholochemical air pollution - its effects on respiratory function of elementary school children. Arch Environ Health 1975;30:117-122

5. Alarie Y. Classification of airborne chemicals that stimulate respiratory tract nerve endings.Crit Rev Taricol 1973;2:229.

6. Saruc M, Fugas M, Hrustic $O$. Effects of urban air pollution on school-age children. Arch Environ Health 1981;36:101-108.

7. Ferris BG. Epidemiology standard isation projecL Am Rev Resp Disease 1978;118(6) Part 2

8. Bouhuys A, Schoenburg JB, Beck, GJ. Growth and decay of pulmonary function in healthy blacks and whites. Resp Physiol 1978;33:367-393.

9. Ware JH, Dockery DW, Spiro A et al. Passive smoking, gas cooking, respiratory health of children living in six cities. Am Rev Resp Disease 1984,1 29:366-374.

10. Mostardi RA, Ely DL, Woebkenberg NR et al. The University of Akron study on air pollution and human health effects (1 \& 2). Arch Environ Health 1981;36:243-255. 